\title{
Rural Income and Employment Generation: Contribution of Common Property Resources in Valley and Hill Districts of Manipur
}

\author{
Janee Yumlembam ${ }^{1 *}$, Y. Chakrabarty Singh ${ }^{2}$, B.K. Bera ${ }^{3}$, A.K. Nandi ${ }^{3}$ and P.K. Sahu ${ }^{4}$
}

${ }^{1}$ Arunachal University of Studies, Namsai- 792103, Arunachal Pradesh, India

${ }^{2}$ Department of Agricultural Economics, College of Agriculture, Central Agricultural University, Iroisemba-795004, Imphal, Manipur, India

${ }^{3}$ Department of Agricultural Economics, Faculty of Agriculture, Bidhan Chandra Krishi Viswavidyalaya, Mohanpur-741252, Nadia, West Bengal, India

${ }^{4}$ Department of Agricultural Statistics, Bidhan Chandra Krishsi Viswavidyalaya, Mohanpur-741252, Nadia, West Bengal, India

*Corresponding author: jane15pooh@gmail.com (ORCID ID: 0000-0002-3362-9257)

Received: $10-04-2019$

Revised: 20-07-2019

Accepted: 25-08-2019

\begin{abstract}
In developing country like India where population is large and unemployment is high, focus on common property resources (CPR) is a must especially in backward regions. Manipur is one of the least developed terminal states in the country which has a total geographical area of 22347 square kilometres (GoM, 2013). Importance of CPRs in the state is multifold. It has been the source of livelihood for several. The study has attempted to identify the sources of household $(\mathrm{HH})$ income, role of CPRs in the livelihood of the people in the state in terms of income and employment generation. Complete enumeration of households and descriptive statistics had been employed to accomplish the study. Identified income sources in the selected valley and hill has been classified under three main sectors viz., farm, non-farm and common property resources (CPRs) income. CPRs based activities in the valley and hill villages vary and generate income and employment to both male and female household members. Income from CPRs based activities contributes 9.38 and 32.59 per cents in the valley and hill village, respectively. In valley village male spends maximum time collecting firewood (22.50 man-days) and females in collection of food items (13.75 man-days). While in hill village, in charcoal making male spends 157.5 man-days and female 135 man-days.
\end{abstract}

\section{Highlights}

( Common property resources like village hill forest, canal, pond and rivulet has served as important means of livelihood for the people in northeast state of Manipur. CPRs generates income $(9.38 \%$ and $32.59 \%$ of annual income per household, respectively in the study villages) and employment (11.25-22.50 man-days and 21.25-157.5 man-days, respectively in the study villages)

(0 Common property resources are the source of food and fuel in the study regions.

0 Female household members play important role in income generation earning an average imputed income of ₹ 11290.00 and $₹ 124104.1$ in valley and hill respectively.

Keywords: Common property resources, Income, Employment, Descriptive statistics, Manipur

Generation of income and employment among the rural people is an important task for the development of an economy and it can be brought through utilization of different types of available resources. Income from agriculture and allied activities plays key role in an agrarian economy like
India. Agricultural activities were the only source of income and employment since human civilization. It is mostly generated through small- scale agriculture, including commodity crops, home gardens, and large and small livestock and aquaculture. However owing to increase population growth 
and globalization, activities outside agricultural activities provides a major share in income and employment. This could be both from farm and nonfarm sources; income from wage labor (farm or nonfarm activities), small scale industries, remittances and other transfer payments, such as assistance from state agencies. In developing country like India where population is large and unemployment is high, focus on common property resources (CPR) is a must especially in backward regions. These provide the base upon which the vast majority of the rural people derive benefits which serves as an alternative source of income and employment.

Manipur is one of the terminal states in our country which has a total geographical area of 22347 square kilometres (GoM, 2013). Out of 9 districts, four are valley districts namely Imphal East, Imphal West, Thoubal, Bishnupur and five under the domain of hill namely Chandel, Churachandpur, Tamenglong, Ukhrul and Senapati. Available tracts of fertile land in Manipur occupy the gross cropped area of 33.5 thousand hectare which accounts for 12.98 per cent of total geographical area (GoM, 2012a). Nearly 50 percent of the gross cropped area in the state is utilized for single crop paddy cultivation (GoM, $2012 b$ ). Employment situation in Manipur is not much encouraging. The states per capita income during 2013-14 were ₹ 41573 and ₹ 24042 at current and constant prices respectively (GoM, 2016). The economy of the state is primarily dependent on agriculture. Despite the crucial importance of agriculture, irregularity and erratic behaviour of monsoon accompanied by inadequate irrigation facilities have resulted in severe fluctuations in agricultural production. Owing to this people have started diversifying their occupation to nonagricultural sectors such as handloom, small scale industries, hotelling, wage-labour etc., as a source of income and employment. Apart from this people depends on CPRs based activities as an alternative source of income and employment generation. It has been reported that of the total land holdings of a $\mathrm{HH} 25$ per cent are common property land resource (GoI, 1999). In Churachandpur district, forests and forest based products are found to be mostly (68 percent cases) used common property resources; every household has access and rights over forests and forest based resources (GoI 2008). Keeping in view the importance of CPRs, the purposed study has analyze the income and employment generating activities and contribution from common property resources in selected villages of two districts namely Imphal East in valley region and Churachandpur in hill region of Manipur, based on the following objectives:

1. Identification and characterization of income generating activities and household participation in the study areas.

2. To assess household income and contribution of CPRs based income.

3. To determine employment generation through CPRs based activities.

\section{METHODOLOGY}

\section{Study area}

\section{Village profile}

\section{Ishingthembi mapan}

Ishingthembi mapan village in Imphal East district has been selected purposively owing to the dependence of the villagers on community common property resources based on pilot survey. The village has 30 HHs in-habited by Meitei community. Rivulet of the main river 'Kongba', Kongba maru flows through the village which is the main source of water for drinking, domestic uses and for irrigating the paddy fields. Firewood is the only medium of cooking for all the HHs. Utilization pattern of CPRs in the village is presented in table 1.

Table 1: Utilization pattern of CPRs in Ishingthembi mapan village

\begin{tabular}{|c|c|c|}
\hline CPRs & Utilization & Area (ha) \\
\hline $\begin{array}{l}\text { Village big pond (Pukhri } \\
\text { achouba) }\end{array}$ & Fish farming & 0.19 ha \\
\hline $\begin{array}{l}\text { Village small pond (Pukhr } \\
\text { imacha) }\end{array}$ & Domestic use & 0.09 ha \\
\hline $\begin{array}{l}\text { Village forest (mountain forest) } \\
\text { area }\end{array}$ & - & - \\
\hline $\begin{array}{l}\text { Kongba-maru (rivulet of } \\
\text { Kongba river) }\end{array}$ & Domestic use & - \\
\hline
\end{tabular}

Source: Village survey.

\section{Lhahvom}

M. Lhahvom is a village in Saikot tehsil located $6 \mathrm{Km}$ towards south from district head quarter Churachandpur, $70 \mathrm{Km}$ from state capital Imphal. 
Akin to all other hill villages in the state, the village land is owned by village chief. It is in-habitat by 50 HHs. Main occupations of the villagers are charcoal production, firewood production and paddy cultivation on leased in basis. More than 50 per cent of the HHs is engaged in charcoal production. Other occupation includes petty business like traders, drivers, etc. Village hill forest and canal are the available common property resources. Produce are either directly sold in the nearest market Damcum (at Churachandpur bazaar) or through traders that comes and collect the produce from the villagers in the village itself. Chief also maintains reserved forest area for conserving trees which is cut down in times of need of money for the village. Utilization pattern of CPRs in the village is presented in table 2.

Table 2: Utilization pattern of CPRs in M. Lhavom village

\begin{tabular}{ccc}
\hline CPRs & Utilization & Area (ha) \\
\hline & Charcoal making & 12.65 ha \\
Village hill & Firewood collection & 9.25 ha \\
forest & Bamboo collection & - \\
Canal & Irrigation, domestic water use & - \\
\hline
\end{tabular}

Source: Village survey.

\section{Sampling}

Two stage sampling technique was followed. In the first stage two districts namely Imphal East from valley region and Churachandpur from the hill region out of total 9 districts in the state was selected purposively. In the second stage one village from each district namely Ishingthembi mapan in Imphal East and M. Lhahvom village in Churachandpur were selected purposively based on pilot survey, where the HHs depends on CPRs. A full household survey was carried out in these sampled villages with the help of a well-structured and pre-tested interview schedule to identify income generating activities, employment status, pattern and dependency on CPRs for income and employment generation.

\section{Delineation of study area}

Table 3: Delineation of study area

\begin{tabular}{ccccc}
\hline $\begin{array}{c}\text { Sl. } \\
\text { No. }\end{array}$ & District & $\begin{array}{c}\text { Sub- } \\
\text { Division }\end{array}$ & $\begin{array}{c}\text { Village } \\
\text { name }\end{array}$ & $\begin{array}{c}\text { Sample size } \\
\text { (Households) }\end{array}$ \\
\hline \multicolumn{4}{c}{ Valley District } \\
\hline 1 & Imphal East & $\begin{array}{c}\text { Sawom- } \\
\text { bung }\end{array}$ & $\begin{array}{c}\text { Ishingthembi } \\
\text { mapan }\end{array}$ & $30 \mathrm{HHs}$ \\
\hline
\end{tabular}

Hill District

\begin{tabular}{c}
\hline $\begin{array}{c}\text { Churachan- } \\
\text { dpur }\end{array}$ \\
$\begin{array}{c}\text { Chura- M. Lhavom } \\
\text { chandpur }\end{array}$ \\
Sources: Collected by the author through village survey.
\end{tabular}

\section{Analytical Tools}

\section{Farm Income:}

- Income from crop/mulberry cultivation = Gross value of output - Cost $\mathrm{C}_{2}$ (CACP concept)

- Income from animal husbandry = Gross value of output - Cost incurred

\section{Cost incurred:}

1. Operational cost: cost of purchasing livestock, feed cost, vaccination cost, miscellaneous charges like repair charges,

2. Fixed cost such as depreciation on fixed assets like coop, water jar, feeder bowl.

Output considered includes: livestock products like milk, meat, eggs.

- Income from vegetable cultivation/Home gardening: Home-garden income was calculated by asking the respondents the amount of homegarden products they had harvested and sold and consumed and how much income was earned from the previous year's sale by recalling method (Pebam, 2013).

- Income earned as agricultural labourers: Based on recalling method of the respondent.

Non-farm income $=$ Non-agricultural labour earnings + Business and trade earnings + Cottage industries/handloom/ weaving

CPRs income: Income from food items, fodder collection, fish, firewood, charcoal, bamboo and jhum cultivation $=$ Value of collected items - (imputed value of labour + hired labour) + depreciation of tools and equipments used + fees if any.

Economic returns from CPRs are estimated by converting all resources and services provided by them into monetary terms. It has been estimated as follows:

CPRs income $=X_{1}+X_{2}+X_{3}+X_{4}+X_{5}+X_{6}+X_{7}+X_{8}$

Where, $X_{1^{\prime}}, X_{2^{\prime}} X_{3^{\prime}} X_{4^{\prime}} X_{5^{\prime}}, X_{6}$ are the imputed values 
of food items, fodder, firewood, charcoal, bamboo, fish respectively; $X_{7}$ is jhum cultivation; $X_{8}$ is the imputed value of fodder grazed on CPRs. For those products which doesn't have market value village prevailing prices of the products have been used as imputed price in case such prices existed in the sample village and if not in the neighbouring village (Gowda, 2008).

Income derived from grazing has been estimated by assessing the quantity of fodder/foliage consumed by animals on CPRs (Nadkami et al. 1989). For estimating the quantity of fodder grazed by the animals of a household, at the first step, all animals of the household have been converted into animal units (Jodha, 1986) on the following basis:

- bullock/cow = 1animal unit,

- I calf or heifer $=0.6$ animal unit

Animal unit grazing days on CPRs have been calculated by multiplying the grazing days with animal units. At least six hours stay of an animal on common grazing land has been considered equivalent to one grazing day (Jodha, 1986). Finally, the quantity of fodder/foliage grazed on CPRs by the livestock of a household has been assessed by multiplying total animal unit grazing days on CPRs with 75 percent of the average daily feed of fodder of an animal unit in the village. The average daily feed of fodder of an animal unit in a sample village has been calculated by taking average daily feed of all types of animal in all seasons (Gowda et al. 2008).

\section{Employment generation through CPRs based activities}

Employment generation in terms of participation of $\mathrm{HH}$ members and engagement in terms of mandays annually, in common property resources based activities. Percentage analysis and tabular presentation has been done to represent employment pattern and status of male and female in the selected study areas out of the total labour force.

\section{RESULTS AND DISCUSSION}

Income generating activities in Ishingthembi mapan and $M$. Lhavom village has been presented in table 4. Income sources have been clubbed under three main sectors namely farm, non-farm and CPRs income. The identified activities under farm income earning sectors were paddy cultivation, vegetable cultivation, animal husbandry, mulberry cultivation and agricultural labour earnings in Ishingthembi mapan. Goswami, et al. (2009) identified income earned from farm activities like crop, livestock and poultry as farm income sources. Highest participation of HHs was recorded in paddy $(100.00 \%)$ and vegetable cultivation (100.00 \%) in Ishingthembi mapan. Non-agricultural labour earnings include wage workers in construction sites, mechanic and daily wage earning activities; business and trade earnings include auto-rickshaw driving.

In a study by Schwarze, (2004), 96 per cent HHs participated in agricultural activities. In M. Lhavom, under farm sources, paddy cultivation and vegetable cultivation are the two main activities participated by 46 and 30 per cent HHs. Ranganathan et al. (2015) reported that in rural India, HHs earn their incomes from various sources including cultivation, livestock, agricultural wage labour and other nonfarm occupations. Under non-farm sources, business and trade earnings includes auto rickshaw driving and hotelling and cottage industries/handloom/ weaving of ponve (traditional clothing of women) by females. 12 per cent of the HHs in M. Lhavom participates in business and trade earnings. In Ishingthembi mapan village, CPRs income sources includes collection of food items, grazing of animals, fodder collection, collection of firewood, fish farming in village pond where, highest $\mathrm{HHs}$ participation was observed in firewood collection (100.00\%) and fishing (100.00\%). And the Identified CPRs income source in M. Lhavom were collection of food items and firewood for free, collection of firewood (paid basis), collection of bamboos (paid basis) and charcoal making (paid basis). Under the paid basis, HHs pays some fees to the village chief. Highest participation was found in collection of food items and firewood for free (100 per cent in each activity).

Table 5 depicts contribution of each main sectors to annual income of HHs. In Ishingthembi mapan, on an average annual income from farm sector was ₹ 97086.37 with a share of 38.69 per cent; non-farm was ₹ 130285.71 with a share of 51.93 per cent and ₹ 23530.33 with 9.38 per cent share to the average annual income per HH. In a study by Ellies, (1999) in South Asia, on average, 60 per cent of rural household income was from non-farm sources. 
Bhakar, (2007) reported from his study that in rural area of Chhattisgarh, overall income was ₹ 39161, which was generated from 23.07 per cent farm, and 69.57 per cent non-farm activities. In $M$. Lhavom, on an average income from farm sector was ₹ 10515.30 with a share of 5.04 per cent; non-farm was ₹ 130080.56 with a share of 62.37 per cent and CPRs ₹ 57834.02 with 32.59 per cent share to the average annual income per $\mathrm{HH}$.

Table 4: Income generating activities in Ishingthembi mapan and M. Lhahvom village in valley and hill region respectively during 2015-16

\begin{tabular}{cccc}
\hline S1. & Activities & $\begin{array}{c}\text { HHs participation (nos.) } \\
\text { Ishingthembi } \\
\text { mo. }\end{array}$ & $\begin{array}{c}\text { M. } \\
\text { Lhahvom }\end{array}$ \\
\hline \multicolumn{4}{c}{ Farm Income } \\
\hline 1 & Paddy cultivation & $\mathbf{3 0}(100.0)$ & $\mathbf{1 4}(46)$ \\
2 & Vegetable cultivation & $\mathbf{3 0}(100.0)$ & $\mathbf{9 ( 3 0 )}$ \\
3 & Animal husbandry & $\mathbf{8}(26.7)$ & - \\
4 & Mulberry Cultivation & $7(23.3)$ & - \\
5 & $\begin{array}{c}\text { Agricultural labour } \\
\text { earnings }\end{array}$ & $\mathbf{1 0}(33.3)$ & - \\
\hline \multicolumn{4}{c}{} \\
\hline
\end{tabular}

\begin{tabular}{|c|c|c|c|}
\hline \multicolumn{4}{|c|}{ Non-Farm Income } \\
\hline 6 & $\begin{array}{l}\text { Non-agricultural } \\
\text { labour earnings }\end{array}$ & $7(23.3)$ & - \\
\hline 7 & $\begin{array}{c}\text { Business and trade } \\
\text { earnings }\end{array}$ & $2(6.7)$ & $4(12)$ \\
\hline 8 & $\begin{array}{l}\text { Cottage industries/ } \\
\text { handloom/ weaving }\end{array}$ & - & $1(4)$ \\
\hline \multicolumn{4}{|c|}{ CPRs Income } \\
\hline 9 & $\begin{array}{l}\text { Collection of food } \\
\text { items }\end{array}$ & $6(20.0)$ & $30(100)$ \\
\hline 10 & Grazing of animals & $3(10.0)$ & - \\
\hline \multirow[t]{2}{*}{11} & Fodder collection & $3(10.0)$ & - \\
\hline & Collection of firewood & $30(100.0)$ & $30(100)$ \\
\hline 12 & $\begin{array}{l}\text { Collection of firewood } \\
\text { paid basis }\end{array}$ & - & $5(18)$ \\
\hline 13 & $\begin{array}{l}\text { Fish farming in village } \\
\text { pond }\end{array}$ & $30(100.0)$ & - \\
\hline 14 & $\begin{array}{l}\text { Collection of bamboos } \\
\text { (paid basis) }\end{array}$ & - & $2(8)$ \\
\hline 15 & $\begin{array}{l}\text { Charcoal making (paid } \\
\text { basis) }\end{array}$ & - & $21(70)$ \\
\hline
\end{tabular}

Sources: Computed by the authors from household survey data.

Figure in BOLD gives absolute number of HHs out of the total $\mathrm{HH}$ in each village; Figure in parenthesis gives \% of total HHs in the each village.

Total HHs in Ishingthembi mapan village $=30 ;$ M. Lhahvom village $=50$.
Table 5: Estimation of percentage contribution of each main sectors of income of HHs to annual income during 2015-16

\begin{tabular}{|c|c|c|c|c|c|}
\hline \multirow[b]{2}{*}{$\begin{array}{l}\text { S1. } \\
\text { No. }\end{array}$} & \multirow[b]{2}{*}{$\begin{array}{l}\text { Main } \\
\text { source of } \\
\text { income }\end{array}$} & \multicolumn{2}{|c|}{$\begin{array}{l}\text { Average annual } \\
\text { income of the HHs } \\
\text { (₹) }\end{array}$} & \multicolumn{2}{|c|}{$\begin{array}{l}\% \text { Contribution to } \\
\text { total income }\end{array}$} \\
\hline & & 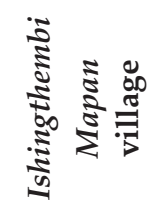 & 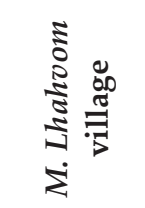 & 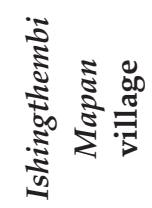 & 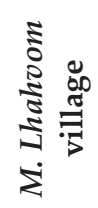 \\
\hline A & $\begin{array}{l}\text { Farm } \\
\text { Income }\end{array}$ & 97086.37 & 10515.30 & 38.69 & 5.04 \\
\hline B & $\begin{array}{l}\text { Non-Farm } \\
\text { Income }\end{array}$ & 130285.71 & 130080.56 & 51.93 & 62.37 \\
\hline C & $\begin{array}{l}\text { CPRs } \\
\text { Income }\end{array}$ & 23530.33 & 57834.02 & 9.38 & 32.59 \\
\hline
\end{tabular}

Average

annual income $250902.41 \quad 198429.88 \quad 100 \quad 100$

$(\mathrm{A}+\mathrm{B}+\mathrm{C})$

Sources: Computed by the authors from household survey data.

Employment pattern of households in Ishingthembi mapan has been presented in table 6. It can be observed that 100 per cent male and female working population are self-employed in vegetable cultivation, followed by paddy cultivation in owned or leased in land (76.12 \% male and $70 \%$ female) under farm sector. As casual labour/irregular employment under farm sector in others' paddy field 14.93 per service as autorickshaw drivers $(2.99 \%)$ and 10.45 per cent Ishingthembi mapan, under non-farm source 2.99 per cent of ale population was found to be self employed in transportation Ishingthembi mapan, under non-farm source 2.99 per cent of male population was found to be self employed in transportation as autorickshaw drivers $(2.99 \%)$ and 10.45 per cent irregular wage earners respectively under the casual labour/ irregular employment category. Female working population were not engaged in any activity under irregular wage earners. As casual labour/ irregular employment under non-farm sector majority of the male workers were engaged as jugali (daily wage earner-10.45\%). In CRRs based activities, majority of the male self employ in firewood collection $(44.78 \%)$ and females in collection of food items (12\%). Overall in Ishingthembi mapan majority of both male and female are self employed in vegetable and paddy cultivation. 
Table 6: Employment pattern of households in Ishingthembi mapan and M. Lhahvom during 2015-16

\begin{tabular}{|c|c|c|c|c|c|}
\hline \multirow{2}{*}{$\begin{array}{l}\text { Sl. } \\
\text { No. }\end{array}$} & \multirow{2}{*}{$\begin{array}{l}\text { Employment } \\
\text { status }\end{array}$} & \multicolumn{2}{|c|}{$\begin{array}{c}\text { Ishingthembi } \\
\text { mapan }\end{array}$} & \multicolumn{2}{|c|}{ M. Lhahvom } \\
\hline & & $\sum_{\Sigma}^{\frac{0}{\pi}} \frac{\varrho}{\varrho}$ & 劳 & $\sum^{\frac{\pi}{\Sigma}} \precsim$ & 䒕 \\
\hline A & Farm sector & & & & \\
\hline \multirow[t]{5}{*}{1} & Self-employment & & & & \\
\hline & $\begin{array}{l}\text { Paddy cultivation } \\
\text { (owned or leased } \\
\text { in field) }\end{array}$ & $\begin{array}{c}\mathbf{5 1} \\
(76.12)\end{array}$ & $\begin{array}{c}35 \\
(70.00)\end{array}$ & $\begin{array}{c}34 \\
(25.76)\end{array}$ & $\begin{array}{c}22 \\
(25.88)\end{array}$ \\
\hline & $\begin{array}{l}\text { Vegetable } \\
\text { cultivation (Home } \\
\text { gardening) }\end{array}$ & $\begin{array}{c}67 \\
(100.00)\end{array}$ & $\begin{array}{c}50 \\
(100.00)\end{array}$ & $\begin{array}{c}\mathbf{5 4} \\
(40.91)\end{array}$ & $\begin{array}{c}32 \\
(37.65)\end{array}$ \\
\hline & $\begin{array}{l}\text { Animal } \\
\text { husbandry }\end{array}$ & $\begin{array}{c}30 \\
(19.40)\end{array}$ & $8(16)$ & $\begin{array}{c}10 \\
(7.58)\end{array}$ & $3(3.53)$ \\
\hline & $\begin{array}{l}\text { Mulberry } \\
\text { cultivation }\end{array}$ & $\begin{array}{c}11 \\
(16.42) \\
\end{array}$ & $7(14)$ & - & - \\
\hline 2 & $\begin{array}{l}\text { Regular wage } \\
\text { employment }\end{array}$ & - & - & - & - \\
\hline 3 & $\begin{array}{l}\text { Casual labour/ } \\
\text { irregular } \\
\text { employment } \\
\text { Paddy cultivation }\end{array}$ & $\begin{array}{c}10 \\
(14.93)\end{array}$ & - & - & - \\
\hline B. & Non-farm sector & & & & \\
\hline \multirow[t]{3}{*}{1} & $\begin{array}{l}\text { Self-employment } \\
\text { Autorickshaw } \\
\text { driving }\end{array}$ & $2(2.99)$ & - & $3(2.27)$ & - \\
\hline & Shop/ Hotelling & - & - & $2(1.52)$ & $4(4.71)$ \\
\hline & $\begin{array}{l}\text { Weaving (Ponve } \\
\text { making) }\end{array}$ & - & - & - & $2(2.35)$ \\
\hline \multirow[t]{2}{*}{2} & \multicolumn{5}{|c|}{ Casual labour/ irregular employment } \\
\hline & $\begin{array}{l}\text { Jugali (irregular } \\
\text { wage earner) }\end{array}$ & $\begin{array}{c}7 \\
(10.45) \\
\end{array}$ & - & - & - \\
\hline C. & \multicolumn{5}{|c|}{ CPRs based activities } \\
\hline \multirow[t]{7}{*}{1} & Self employment & & & & \\
\hline & $\begin{array}{l}\text { Collection of food } \\
\text { items }\end{array}$ & - & $6(12)$ & $\begin{array}{c}32 \\
(24.24)\end{array}$ & $\begin{array}{c}45 \\
(52.94)\end{array}$ \\
\hline & $\begin{array}{l}\text { Collection of } \\
\text { fodder }\end{array}$ & $3(4.48)$ & - & - & - \\
\hline & $\begin{array}{l}\text { Collection of } \\
\text { firewood (free) }\end{array}$ & $\begin{array}{c}30 \\
(44.78)\end{array}$ & - & $\begin{array}{c}60 \\
(45.45)\end{array}$ & $\begin{array}{c}57 \\
(67.06)\end{array}$ \\
\hline & $\begin{array}{l}\text { Collection of } \\
\text { firewood paid }\end{array}$ & - & - & $\begin{array}{c}17 \\
(12.88)\end{array}$ & - \\
\hline & $\begin{array}{l}\text { Collection of } \\
\text { bamboos (paid } \\
\text { basis) }\end{array}$ & - & - & $\begin{array}{c}16 \\
(12.12)\end{array}$ & - \\
\hline & $\begin{array}{l}\text { Charcoal making } \\
\text { (paid basis) }\end{array}$ & - & - & $\begin{array}{c}50 \\
(37.88) \\
\end{array}$ & $\begin{array}{c}17 \\
(20.00) \\
\end{array}$ \\
\hline
\end{tabular}

Sources: Computed by the authors from household survey data.

Figure in BOLD gives absolute value; Figure in parenthesis gives $\%$ age of total male and female workforce in each village; Ishing thembi mapan: male worker $=67 ;$ female worker $=50 ;$ M. Lhavom : male worker $=132$; female worker $=85$.
Table 7 depicts employment status in the study areas. Time devoted expressed in man-days and average wage per annum per person under each categorised activities has been presented. In Ishingthembi mapan male devote maximum time (250 man-2.27 per cent male engaged themselves as auto rickshaw driver with average annual wage per male of ₹ 70000.00 followed by casual labour/ irregular employment with 157.5 man-days earning on an average ₹ 45000.00 per annum per male. And females in animal husbandry (15.21 man-days) followed by vegetable cultivation ( 15 man-days) earning ₹ 1875.00 and ₹ 4562.50 per annum per female respectively.

In M.Lhavom majority of male (40.91\%) and female $(37.65 \%)$ were engaged in vegetable cultivation under farm sector self employment.

Overall in the village, male devotes maximum time in non-farm self-employment category and female in farm self employment category. Maximum wage was also from the respective categories mentioned. Under farm source self-employment category in M.Lhavom both male and female devotes maximum time in paddy cultivation (26.15 and 22.5 man days respectively). Average wage per annum per person was $₹ 7218.75$ and $₹ 6187.50$ respectively. In M. Lhavom male spend 200 man-days as self employed under non-farm earning an average wage of ₹ 86155.56 per annum per person and female in hotelling activity (300 man-days) earning $₹$ 113333.33. It can be concluded that in the hill village, male and female are mainly self-employed under non-farm sector. Maximum wage was also from the identified categories of employment.

\section{CONCLUSION}

Identified income generating activities in both the regions has been classified under three main sectors viz., farm, non-farm and common property resources (CPRs) income. The identified activities in valley village were paddy cultivation, vegetable cultivation, animal husbandry, mulberry cultivation and agricultural labour earnings, wage workers in construction sites, mechanic and daily wage earning activities; business and trade earnings include auto-rickshaw driving. In the hill village there were paddy cultivation and vegetable cultivation, auto rickshaw driving and hotelling and cottage industries/handloom/ weaving refers to ponve 
Table 7: Employment status in Ishingthembi mapan and M. Lhahvom village in valley and hill regions during 2015-16

\begin{tabular}{|c|c|c|c|c|c|c|c|c|c|}
\hline \multirow{3}{*}{ S1. No } & \multirow{3}{*}{ Activities } & \multicolumn{4}{|c|}{ Ishingthembi mapan } & \multicolumn{4}{|c|}{ M. Lhahvom } \\
\hline & & \multicolumn{2}{|c|}{ Man-Days } & \multicolumn{2}{|c|}{$\begin{array}{l}\text { Average wage per } \\
\text { annum per (₹) }\end{array}$} & \multicolumn{2}{|c|}{ Man-Days } & \multicolumn{2}{|c|}{$\begin{array}{l}\text { Average wage per } \\
\text { annum per (₹) }\end{array}$} \\
\hline & & Male & Female & Male & Female & Male & Female & Male & Female \\
\hline A. & Farm sector & & & & & & & & \\
\hline \multirow[t]{5}{*}{1} & Self-employment & & & & & & & & \\
\hline & $\begin{array}{l}\text { Paddy cultivation (owned or } \\
\text { leased in field) }\end{array}$ & 22.5 & 11.25 & 5625.00 & 2812.50 & 26.25 & 22.5 & 7218.75 & 6187.50 \\
\hline & $\begin{array}{l}\text { Vegetable cultivation (Home } \\
\text { gardening) }\end{array}$ & 10 & 15 & 3750.00 & 1875.00 & 18.75 & 18.75 & 3750.00 & 3750.00 \\
\hline & Animal husbandry & 30.42 & 15.21 & 9126.00 & 4582.50 & - & - & - & - \\
\hline & Mulberry cultivation & 10.85 & 7.6 & 2170.00 & 1520 & - & - & - & - \\
\hline \multirow[t]{3}{*}{2} & Casual labour/ irregular empl & oyment & & & & & & & \\
\hline & Paddy cultivation & 11.25 & - & 2040.00 & - & - & - & - & - \\
\hline & Total & 85.02 & 49.06 & 22710 & 10770 & 45 & 41.25 & 10968.75 & 9937.5 \\
\hline B. & Non-farm sector & & & & & & & & \\
\hline \multirow[t]{4}{*}{1} & Self-employment & & & & & & & & \\
\hline & Autorickshaw driving & 250 & - & 70000.00 & - & 200 & - & 86155.56 & - \\
\hline & Shop & - & - & - & - & - & 250 & - & 93333.33 \\
\hline & Weaving & - & - & - & - & - & 187.5 & - & 37500.00 \\
\hline \multirow[t]{3}{*}{2} & Casual labour/ irregular empl & byment & & & & & & & \\
\hline & Jugali & 157.5 & - & 45000.00 & - & - & - & - & - \\
\hline & Total & 407.5 & - & 115000 & - & 200 & 218.75 & 86155.56 & 65416.665 \\
\hline C. & CPRs based activities & & & & & & & & \\
\hline \multirow[t]{8}{*}{1} & Self employment & & & & & & & & \\
\hline & Collection of food items & - & 13.75 & - & 520.00 & 21.25 & 25 & 4250 & 5000 \\
\hline & Collection of fodder & 11.25 & - & 1125.00 & - & - & - & - & - \\
\hline & Collection of firewood (free) & 22.50 & - & 6750.00 & - & 35 & 40 & 8750 & 10000 \\
\hline & $\begin{array}{l}\text { Collection of firewood (paid } \\
\text { basis) }\end{array}$ & - & - & - & - & 150 & - & 42000 & - \\
\hline & $\begin{array}{l}\text { Collection of bamboos (paid } \\
\text { basis) }\end{array}$ & - & - & - & - & 17.97 & - & 3593.75 & - \\
\hline & Charcoal making (paid basis) & - & - & - & - & 157.5 & 135 & 39375 & 33750 \\
\hline & Total & 33.75 & 13.75 & $\mathbf{1 2 9 3 7 . 5 0}$ & 520.00 & 76.34 & 66.67 & 97968.75 & 48750 \\
\hline
\end{tabular}

Sources: Computed by the authors from household survey data; Values are in average.

(traditional clothing of women) weaving. CPRs income sources includes collection of food items, grazing of animals, fodder collection, collection of firewood, fish farming in village pond in the valley village and collection of food items and firewood for free, collection of firewood (paid basis), collection of bamboos (paid basis) and charcoal making (paid basis) in hill village. Average incomes from CPRs were ₹ 23530.33 and ₹ 57834.02 respectively in the valley and hill village. In the valley village female spends 13.75 man-days collecting food items per annum and male spends 11.25 and 22.50 mandays collecting fodders and firewood respectively. Whereas in hill village male and female spends 21.25 man-days and 25 man-days respectively collecting food items; 35 man-days and 40 man-days respectively by the male and female $\mathrm{HH}$ members collecting firewood for home consumption. Apart from theses they spend 157.5 and 135 man-days in charcoal making respectively. Overall income of 
HHs in the study villages were lesser than 3 lakhs annually ( $₹ 250902.41$ in the valley and ₹ 198429.88 in the hill), of which 9.38 and 32.59 per cents were from CPRs income respectively. HHs was self employed in CPRs based activities for 47.5 mandays in valley and 581.72 man-days in hill annually.

\section{REFERENCES}

Bhakar, R., Banafar, K.N.S., Singh, N.P. and Gauraha A.K. 2007. Income and employment pattern in rural area of Chhattisgarh: a micro view. Agricultural Economics Research Review, 20: 395-406.

Ellis, F. 1999. Rural livelihood diversity in developing countries: evidence and policy implications, Natural Resource Perspectives, 40.

GoI. 1999. Common property resources in India, NSS $54^{\text {th }}$ round -January 1998 June 1998. National Sample Survey Organisation Department of Statistics and Programme Implementation Government of India.http://mospi.nic. in /sites/default/files/publication_reports/452_final.pdf

GoM. 2012a. Department of Agriculture, Manipur. Government of Manipur, ii.

GoM. 2013. Economic Survey 2013, Manipur. Directorate of Economics and Statistics, Government of Manipur, pp. 21.

GoM. 2016. Economic Survey 2015-16, Manipur, Directorate of Economics and Statistics, Government of Manipur, 26.
GoM. 2012b. State level banker's committee, various issues (2004-05 to 2011-12), lead bank, SBI. Government of Manipur.

Goswami, U.K., Ali, R.N. and Farid, K.S. 2009. Rural women in income earning activities: an impact assessment. Bangladesh Journal of Agricultural Sciences, 36: 23-36.

Gowda, N.K.S., Prasad, C.S., Selvaraju, S., Reddy, I.J., Anantharam, K. and Sampath, K.T. 2008. Feeding practices and nutrient status of dairy cows under field conditions. Indian Vet. J., 85: 745-748.

Jodha, N.S. 1986. Common property resources and rural poor. Economic and Political Weekly, 21(5): 1169.

Nadakarni, M.V., Pasha, S.A. and Prabhakar, L.C. 1989. The political Economy of forest use management. Sage Publications, New Delhi.

Pebam, R. 2013. Socio-economic and ecological studies in home gardens of undivided Aizawl district of Mizoram India. Ph.D Thesis submitted to the department of forestry, Mizoram University.

Ranganathan, T., Tripathi, A. and Rajoriya, B. 2015. Income and income inequality among Indian rural households. www.nird.org.in/nird_docs/srsc/srsc261016-1.pdf

Schwarze, S. 2004. Determinants of income generating activities of rural households: a quantitative study in the vicinity of the lore-lindu national park in central Sulawesi/ Indonesia. Ph.D thesis submitted to the department of Economics, Göttingen University. 